\title{
CZY LITERATURA POTRAFI „MÓWIĆ KULINARIAMI”? NA PRZYKŁADZIE KATEGORII STAROŚCI I MŁODOŚCI
}

Artykuł poświęcony jest ukazaniu, w jaki sposób sceny kulinarne korespondują z kategoriami starości i młodości. W pierwszej części zostały omówione wybrane powieści tendencyjne XIX wieku, w drugiej — proza doby realizmu socjalistycznego. Teksty te charakteryzują się rozmaitym stopniem nasycenia kulinarnością ${ }^{1}$, począwszy od enumeracji przekąsek i potraw, po (zazwyczaj obszerniejsze od tych) bloki kulinarne, które na stałe zapisały się w pamięci czytelników.

Analizie poddane zostały przede wszystkim pierwsze z wymienionych, czyli tzw. kulinaria akcydensowe ${ }^{2}$, które zazwyczaj nie oddziałują na czytelnika tak mocno jak

\begin{abstract}
*Anna Ż.M. Wiśniewska-Grabarczyk — jej zainteresowania skupiają się na literaturze obszarów trzecich (ze szczególnym uwzględnieniem literatury kulinarnej) oraz cenzurze okresu PRL-u. W 2015 roku ukażą się jej studia w „Przeglądzie Orientalistycznym” (Pragmatographia de legitimo usu ambrozji tureckiej, czyli rozważania Tadeusza Krusińskiego o kawie), w „Dziejach Najnowszych” (recenzja tomu „Nie należy dopuszczać do publikacji”. Cenzura w PRL, red. G. Gzella i J. Gzella) oraz w „Acta Universitatis Lodziensis. Folia Litteraria Polonica" ((Nie)cenzuralne gry PRL-u z kuchnią. Na przykładzie prasy łódzkiej). Wygłosiła dotąd referaty na siedmiu konferencjach ogólnopolskich. Czynnie uczestniczy w życiu studenckim: była m.in. zastępcą przewodniczącego Koła Miłośników Oświecenia oraz redagowała Biuletyn Dialektologiczny. Od sierpnia 2014 roku współpracuje z Muzeum Ziemi Nadnoteckiej przy projekcie badawczym mającym na celu zbieranie i opracowanie przepisów kulinarnych napływowej ludności okolic Trzcianki. Przedsięwzięcie zwieńczyła książka poprzedzona jej wstępem pt. Pamięć smaku mieszkańców Trzcianki $i$ okolic. Prace popularnonaukowe ogłaszała m.in. w „Kuchni. Magazynie dla Smakoszy” (Kawa, kobiety i śpiew, Podekscytowana świnia, czyli jak futuryści prześladowali makaron). Była także jurorką na Festiwalu Dobrego Smaku. Opublikowała kilka recenzji i omówień czasopism i książek m.in. w „Gazecie Wyborczej”, Krytyce Politycznej, Kulturze Liberalnej, Witrynie Czasopism, „Rymsie”, Femce, Polygamii. W 2011 roku w „Twórczości” ogłosiła swój debiut prozatorski - Miniatury kulinarne.

${ }^{1}$ Kategoria stopnia kulinarności (tekstu literackiego niebędącego tekstem kulinarnym) w najogólniejszym znaczeniu daje możliwość rozpatrywania utworu w perspektywie obecnych w nim scen związanych z przygotowywaniem i spożywaniem pokarmów. Używana w odniesieniu do literatury pięknej pozwala odpowiedzieć na kilka pytań podstawowych dla badacza kulinariów: z jaką intensywnością sfera kulinarna jest przedstawiana w danym dziele literackim; na ile z nawyków żywieniowych bohaterów literackich da się stworzyć użyteczną w świecie pozaliterackim książkę kucharską; czy na podstawie opisów posiłków i zwyczajów jedzeniowych bylibyśmy w stanie odtworzyć kulturę stołu społeczeństwa (grupy społecznej) opisanego w utworze? W konsekwencji badanie literatury pięknej przy pomocy takich narzędzi metodologicznych, jak kategoria stopnia kulinarności może pozwolić m.in. na stworzenie typologii scen kulinarnych.

${ }^{2}$ Zaproponowany triadyczny podział scen kulinarnych jest oparty na kryterium formalnym i obejmuje: przepisy, kulinaria akcydensowe i bloki kulinarne. Godne uwagi jest albo graficzne wyodrębnienie
\end{abstract}


rozbudowane i wysmakowane opisy obiadów, rautów, pikników czy wieczerzy wigilijnych. Dostarczają jednak informacji o nawykach żywieniowych i kulturze stołu danej epoki. Ponadto za takimi „niewinnymi” scenami kryje się kod kulinarny ${ }^{3}$, którego odkrycie jest możliwe dopiero przy szerokiej perspektywie literacko-kulturowej. Jak choćby w wypadku herbaty, od której rozpoczniemy rozważania na temat korelacji między młodością a kulinariami ${ }^{4}$.

\section{PARZENIE I PODAWANIE HERBATY — PRZYWILEJ PANIEN NA WYDANIU}

Obecność herbaty w polskich domach zaświadczona jest od XVII wieku' . Mniej więcej w tym samym czasie do Polski dotarła kawa i oba te napoje powoli zaczęły zdobywać uznanie Polaków (nie od razu i nie u wszystkich wzbudzały entuzjazm)' gdyż, jak każdy Inny, potrzebowały trochę czasu, by stać się częścią kultury stołu starego kontynentu.

przepisu kulinarnego, albo występująca w danym fragmencie ilościowa przewaga słownictwa związanego z jedzeniem. O tabuizacji jedzenia zob. m.in. Pokarmy i jedzenie w kulturze. Tabu, dieta, symbol, red. K. Łeńska-Bąk, Opole 2007.

${ }^{3}$ Kod kulinarny rozumie się tu jako podtyp kodu kulturowego, który funkcjonuje na zasadzie intuicyjnie zrozumiałego w obrębie danej społeczności. O znaku kulturowym w perspektywie kulinariów piszą m.in. R. Barthes, Befsztyk i frytki, [w:] tenże, Mit i znak. Eseje, Warszawa 1970, s. 69-71; A. M. Bąbel, Muza $z$ warzachwiq. Uwagi o literaturze i kulinariach, Warszawa 2004; C. Lévi-Strauss, Trójkąt kulinarny, przekł. S. Cichowicz, „Twórczośč 1972, nr 2, s. 71-80. Jednym z obecnie funkcjonujących kodów kulinarnych jest charakterystyczna dla subkultury hipsterskiej tęsknota za daniami z barów mlecznych. Żeby trafnie odczytać tę specyficzną nostalgię, niezbędna jest wiedza z zakresu zbiorowego żywienia obywateli okresu PRL-u — żywienie to Andrzej Fiedoruk nazwał „dowodem pogardy dla jakichkolwiek komfortów życia codziennego” (A. Fiedoruk, Prywatne smaki PRL-u, Poznań 2011, podpis na 6. stronie wklejki ze zdjęciami). Hipsterzy tęsknią za PRL-owską kuchnią z barów mlecznych, która — z jednej strony kojarzy się z czasami ich dzieciństwa, z drugiej strony jest jednym z fundamentów państwa opiekuńczego, co, z uwagi na przeważnie lewicowe poglądy tej subkultury, jest nie bez znaczenia. W tym wypadku kod kulinarny jest przykładem tzw. snobizmu symbolicznego, kiedy to rynkowa wartość dania typowego dla PRL-owskiej jadłodajni może być kilkakrotnie zawyżona w stosunku do jego wartości rzeczywistej (jedzenie ma tylko „grać” tanie). Poruszany w artykule problem relacji między kategorią młodości a kulinariami jest zatem obecny nie tylko w przestrzeni literackiej, ale dotyczy i przestrzeni publicznej (pozaliterackiej).

${ }^{4} \mathrm{Na}$ tę korelację zwróciła uwagę m.in. A. M. Bąbel, dz. cyt., s. 103-106.

${ }^{5}$ Pierwszy transport herbaty dotarł do Europy w 1610 roku dzięki najważniejszemu wówczas na świecie koncernowi międzynarodowemu Vereenigde Oostindische Compagnie (VOC, Holenderska Kampania Wschodnioindyjska). Założone w 1602 roku przedsiębiorstwo było pierwszą tego typu inicjatywą i przez długi okres miało monopol na handel z krajami azjatyckimi, umożliwiając staremu kontynentowi zapoznanie się z wieloma orientalnymi przyprawami czy używkami. O VOC zob. L. Yong, The Dutch East India Company's tea trades with China: 1757-1781, Leiden 2006. Do Polski herbata dotarła w połowie XVII wieku i była pita m.in. na dworze Wazów, gdzie największą jej amatorką była królowa Ludwika Maria Gonzaga (zob. E. Wenland, Kawa, herbata i czekolada. Nowe napoje w osiemnastowiecznej Rzeczypospolitej — ich wptyw na życie codzienne, Torun 2008, s. 61-62).

${ }^{6} \mathrm{O}$ kawie i herbacie zob. B. Hohenegger, Liquid jade. The story of tea from East to West, 2007; H. Szymanderska, Herbata, Warszawa 2004; K. Tarasiewicz, Kawa i herbata na ziemiach polskich. Handel, konsumpcja, obyczaje, Warszawa 2009; E. Wendland, dz. cyt.; o pierwszej polskiej drukowanej książeczce na temat kawy piszę w artykule Pragmatographia de legitimo usu ambrozji tureckiej, czyli rozważania Tadeusza Krusińskiego o kawie (tekst ukaże się w 2015 r. w „Przeglądzie Orientalistycznym”). 
Już w dobie zaborów herbata i kawa były stałymi elementami polskiej kuchni, co więcej, w tym też okresie możemy mówić o stratyfikacji upodobań - herbatę pijała Kongresówka, kawa była częstsza w zaborze austriackim (przygotowana na sposób wiedeński) ${ }^{7}$. Nie bez znaczenia był też sposób podawania tych trunków. Czaj pity ze szklanek przyszedł do Polski ze wschodu i zadomowił się przede wszystkim w zaborze rosyjskim ${ }^{8}$. W filiżankach gustował zachód Europy, a ten sposób spożywania obu używek przejęła u nas przede wszystkim Galicja.

Herbata stała się częstym elementem powieściowych scen kulinarnych, jednak sfunkcjonalizowanym do kategorii kulinariów akcydensowych — herbatę się popija, herbatą się częstuje, jest ona pretekstem do spotkania towarzyskiego. Rozbudowaniem tej akcydensowej sceny kulinarnej jest informacja o rodzaju spożywanego naparu. O tym, jaką herbatą delektują się bohaterowie, informuje czytelnika nie odrębny przepis, a wbudowana w tok powieściowy scena kulinarna. Dostarczała ona nierzadko informacji o tym, kto podawał herbatę i kogo się na herbacie gościło. Te, wydawałoby się, mało ważne dane są kluczowe dla dalszych rozważań.

W XVIII i XIX wieku parzenie i podawanie herbaty w zaciszu domowym było domeną młodych kobiet?:

Umiejętność robienia dobrej herbaty stanowiła minimum wymaganej od dziewcząt edukacji kulinarnej. Niestety nawet to minimum okazywało się niekiedy niebosiężnym szczytem ${ }^{10}$,

7 Taka stratyfikacja upodobań jest jednym z przykładów wpływu kuchni zaborców na kuchnię polską.
O różnych obliczach kulinariów w okresie zaborów zob. m.in. W kuchni i za stołem. Dystanse i prze-
nikanie kultur, red. T. Stegner, Gdańsk 2003 . W szerszej perspektywie jest to przykład (wzajemnego)
oddziaływania kultury materialnej wspólnot pozostających z sobą w kontakcie. Związki te mogły być
wynikiem kontaktów pokojowych (por. włoszczyzna sprowadzona do Polski dzięki królowej Bonie) bądź
wojennych (wspomniana herbata pita na sposób rosyjski czy wysoko ceniona przez Rzymian kuchnia
podbitych przez nich Greków).
${ }^{8}$ Bohaterowie literaccy XIX wieku ochoczo pijali herbatę ze szklanek, jak choćby Szuman, który „wypił
szklankę herbaty z cytryną i poszedł do siebie”, opuszczając pokój Ignacego Rzeckiego. Co ciekawe, her-
bata, na którą „po hucznym obiedzie” stary subiekt zaprosił doktora, była przygotowana w samowarze
(B. Prus, Lalka, t. 1, Warszawa 1964, s. 277-278). Ten rosyjski sposób parzenia czaju nie zadomowił się
w Polsce na długo, podczas gdy herbata i kawa podawane w szklankach, (nierzadko) w koszyczku i na
talerzyku (podstawce), dominowały nie tylko w instytucjach zbiorowego żywienia PRL-u, ale stały się
częścią powojennej kultury stołu także w domach prywatnych.

${ }^{9}$ Omawiając przykłady dokonuje się pewnego uproszczenia na temat rodziny końca XVIII i XIX wieku, która nie była zwartą, homogeniczną grupą. Więcej na ten temat zob. C. Kuklo, Odmienność rytmów rozwoju? Rodziny europejskie, rodziny polskie na przetomie XVIII i XIX wieku, [w:] Rodzina — prywatność — intymnośc. Dzieje rodziny w kontekście europejskim, Warszawa 2005, s. 11-30; M. Żyromski, XIXwieczna rodzina polska, „Roczniki Socjologii Rodziny. Studia socjologiczne oraz interdyscyplinarne”, red. Z. Tyszka, R. 12: 2000, s. 173-188.

Przywołane w artykule cytaty odnoszą się przede wszystkim do rodzin mieszczańskich sportretowanych przez literaturę drugiej połowy XIX wieku.

${ }^{10}$ A. M. Bąbel, dz. cyt., s. 104. 
dlatego zdolność tę tym bardziej cenił sobie przyszły mąż $\dot{z}^{11}$ W środowisku mieszczańskim drugiej połowy XIX wieku kobieta była nadal definiowana przez swoją przydatność do roli żony ${ }^{12}$. W tym kontekście parzenie herbaty i częstowanie nią kandydata do ręki zbliżało pannę do zamążpójścia i było sygnałem dla adoratora, że odebrała ona nie tylko dobre, ale i użyteczne wychowanie ${ }^{13}$.

Herbatę parzyły i podawały córki na wydaniu oraz młode mężatki. Należy odnotować, że cała sfera kuchni w domach prywatnych leżała w gestii kobiet. Zatem i dojrzałe panie domu serwowały napoje, lecz w ich przypadku czynność ta miała zgoła odmienną funkcję ${ }^{14}$.

Co ciekawe, samodzielne przygotowanie i odpowiednie podanie napoju było traktowane jako jeden z atutów panny na wydaniu nie tylko w europejskim kręgu kulturowym. Podnoszone jest $\mathrm{w}$ pracach naukowych omawiających japoński ceremoniał parzenia herbaty ${ }^{15}$, dość wspomnieć artykuł Barbary Lynne Rowland Mori, w którym autorka napisała, iz „chado (the Japanese tea ceremony) is one of the arts a woman learns as parts of preparation for marriage" ${ }^{16}$.

${ }_{11}$ Przykłady mężczyzn mających na uwadze odpowiednie wykształcenie żony w zakresie prowadzenia
domu znajdziemy nie tylko w literaturze polskiej. Dawid Copperfield, świadomy swojego trudnego po-
łożenia finansowego, jeszcze przed ślubem namawiał dziecinną Dorę Spenlow do wdrażania się w nauki
gospodarskie, prosząc, „by zmieniła swój tryb życia”. Niezrażony tym, że Dora stroiła „zagniewane minki”
„stulając usteczka jak pączek róży”, młodzieniec z Blunderstone przyniósł ukochanej „ślicznie oprawiony
zbiór kucharskich przepisów”, które tylko „nabawiły ją bólu głowy”. Także wykłady młodzieńca o sposo-
bach oszczędnego gospodarowania w ich przyszłym domu (np. wskazówki dotyczące wyboru najlepszej
baraniny) prowadzone „w czasie sobotnich przechadzek” niewiele przynosiły rezultatów (K. Dickens,
Dzieje, przygody, doświadczenia i zapiski Dawida Copperfielda, juniora rodem z Blunderstone (których nigdy
ogłaszać drukiem nie zamierzat), przekł. W. Zyndram-Kościałowska, Warszawa 1967, s. 549).
${ }_{12}$ Umiejętność prowadzenia gospodarstwa domowego była mile widziana zarówno w bogatych, jak też
biedniejszych domach. Zmienny był jedynie zakres obowiązków gospodyń, w dużej mierze uzależniony od
kondycji finansowej rodziny. W mniej zamożnych rodzinach kobieta prowadziła dom samodzielnie, a jeśli
status majątkowy na to pozwalał, mogła mieć do pomocy większą bądź mniejszą liczbę służby. W domach
najzamożniejszych zadaniem kobiety było nadzorowanie prac w gospodarstwie, wydawanie dyspozycji, usta-
lanie tygodniowego menu, itp., czyli coś, co dziś nazwalibyśmy zarządzaniem zasobami ludzkimi. ${ }^{13} \mathrm{O}$ edukacji młodych kobiet w XIX wieku zob. B. Kalinowska-Witek, W rodzinie i dla rodziny... Edukacja dziewcząt na przełomie XIX i XX wieku w wybranych czasopismach Królestwa Polskiego, Lublin 2012.

${ }^{14} \mathrm{~W}$ wypadku dojrzałych pań domu nie szło o zaprezentowanie swoich umiejętności pretendentowi do ręki, gdyż kobiety te albo były już zamężne, albo były starymi pannami. Parzenie herbaty było tylko jedną z umiejętności, które wchodziły w zakres prowadzącej całe gospodarstwo domowe pani domu, i jako takie mogło być sygnałem dla gości lepszego bądź gorszego wywiązywania się z tej roli.

${ }^{15}$ Należy podkreślić wyjątkowość japońskiego ceremoniału parzenia herbaty na tle kultury europejskiej. Nawet uwzględniając szerzące się od XVIII wieku angielskie five-o-clocks, czy polskie tzw. fajfy znamienne dla dwudziestolecia międzywojennego, zauważymy, że nie mają one tak ceremonialnego charakteru jak japońskie, pełniąc jednak nadal funkcję socjalizująca. Europejskie spotkania przy herbacie nigdy nie były tak skodyfikowane jak te z Kraju Kwitnącej Wiśni, gdzie każda z czynności ceremoniału miała długą tradycję i bogatą symbolikę. Zestawiając te dwa, w pewnym sensie, tak odmienne sposoby spędzania czasu, nie zwraca się uwagi na sam rytuał, ale na konsekwencje, jakie daje umiejętność parzenia herbaty przez młode kobiety.

${ }^{16}$ B. Lynne Rowland Mori, The tea ceremony: a transformed Japanese ritual, „Gender and Society” 1991, t. 5, nr 1, s. 86-97; „chado (japoński ceremoniał parzenia herbaty) to jedna z umiejętności, którą kobie- 
Młode dziewczęta pielęgnowały umiejętność podawania herbaty także dla najbliższych członków rodziny, nie tylko dla kandydatów do ręki. Jak ważnym momentem dnia jest wspólne wypicie napoju, świadczy kilka fragmentów z Wesołej teorii i smutnej praktyki Elizy Orzeszkowej:

Czas już, mój ojcze, abyś się napił herbaty; potem wybierz książkę, którą chcesz, abym ci dziś czytała. Pójdę i wnet wszystko, co potrzeba urządziwszy, powrócę.

Wstała; przechodząc mimo ojca rzuciła mu uśmiech pogodny jak niebo i spojrzenie przezroczyste jak kryształ i zniknęła za drzwiami przyległego pokoju ${ }^{17}$.

Umiejętność własnoręcznego przygotowania herbaty była ceniona także po zamążpójściu, szczególnie w pierwszym okresie wspólnego życia. Niezwykle wymowny jest fragment z Pana Graby Elizy Orzeszkowej, która napisała: „w ładnej stołowej, o czterech oknach sali, o jedenastej godzinie z rana siedziała przy stole zastawionym herbatą po angielsku, ośmnastoletnia pani Klońska” ${ }^{18}$. Młoda mężatka „siedziała przy stole sama jedna w białym muślinowym penioarze” ${ }^{19}$, gdy w końcu „otworzyły się drzwi i do jadalnej sali wszedł Stanisław Kloński w eleganckim rannym ubraniu i z zaspanymi oczami”20. Mąż poprosił Cesię o herbatę, która przejęta drobiazgowym opisaniem kapelusza, jaki sobie wczoraj kupiła, „lejąc do szklanki gorącą wodę z imbryka”"21, „krzyknęła nagle, — sparzyłam sobie rękę! I odskoczywszy od stołu, upuściła z rąk imbryk i ze łzami w oczach zaczęła dmuchać na białą oparzoną rączkę" 22 . Z dalszej wymiany zdań wynika, że to nie pierwszy raz, gdy pani Klońska parzyła sobie ręce, parząc (nomen omen) herbatę mężowi. „Państwo Stanisławowie Klońscy byli bogaci”23, mieli służbę, dlaczego zatem gospodyni nie chciała scedować obowiązu na gosposię czy lokaja?

Lepiej byś zrobiła Cesiu, żebyś kazała nalewać herbatę pannie służącej, bo sama zawsze sobie tylko ręce poparzysz i nic więcej, — rzekł z pewną niecierpliwością Stanisław, biorąc jednak rękę żony i oglądając ją bardzo troskliwie.

Otóż będę nalewała sama i pokażę ci, że nie jestem tak niezgrabna, jak się tobie zdaje, — odparła z determinacją Cesia, i poważnie, milcząc, zaczęła znowu nalewać herbatę.

ta przyswaja jako element przygotowania do małżeństwa” (przekł. A. Wiśniewska-Grabarczyk). Należy zauważyć, że „pierwotnie chado było zarezerwowane wyłącznie dla mężczyzn” („Chado began as an activity exclusively for men”, B. Lynne Rowland Mori, dz. cyt., s. 87 (przekł. A. Wiśniewska-Grabarczyk). Z biegiem czasu do chado były dopuszczane kobiety, początkowo w zaciszu domowym asystujące swoim mężom w ceremonii.

${ }^{17}$ E. Orzeszkowa, Wesoła teoria i smutna praktyka. Opowiadanie, Warszawa 1966, s. 165.

${ }^{18}$ Taż, Pan Graba, Lwów 1872, s. 93.

${ }^{19}$ Tamże, s. 94.

${ }^{20}$ Tamże.

${ }^{21}$ Tamże, s. 96.

${ }^{22}$ Tamże.

${ }^{23}$ Tamże, s. 92. 
Przecież papie zawsze sama nalewałam, — wyrzekła z rodzajem dumy, stawiając pełną szklankę przed mężem i pijąc sama także herbatę $e^{24}$.

Pani Klońska miała silne poczucie obowiązku i była przekonana, że pewne prace w domu powinna wykonywać osobiście ${ }^{25}$.

Należy podkreślić, że przywilej własnoręcznego parzenia i serwowania herbaty przez młode kobiety to tylko jedna z charakterystycznych dla drugiej połowy XIX wieku cech kultury stołu. Była ona wypadkową zarówno długiej tradycji, jak i wszystkich zmian, jakie dotykały rodzinę mniej więcej od końca XVIII wieku, a nasiliły się w kolejnych fazach rewolucji przemysłowej w XIX wieku ${ }^{26}$. Relacje międzypokoleniowe ulegały redefinicji na różnych płaszczyznach, obejmując również tak powszechną czynność, jak przygotowanie i spożywanie posiłków (będących składową prowadzenia całego gospodarstwa domowego). Zauważalne w Europie przemiany obejmujące rodzinę miały kilka podstawowych przyczyn ${ }^{27}$, natomiast najważniejsze dla obecnych rozważań konsekwencje tego procesu to wzrost roli kobiety w samodzielnym prowadzeniu domu ${ }^{28}$. Szczególnie na ziemiach Rzeczypospolitej uwidaczniają się te okresy, w których panie domu przejmowały w całości opiekę nad gospodarstwem. W czasie licznych zrywów powstańczych i działań konspiracyjnych XIX wieku, pod nieobecność gospodarza, to kobieta przejmowała wszystkie jego obowiązki, poszerzając i tak długą listę zajęć zwyczajowo do niej należących. Najpełniej ten proces daje się zaobserwować w literaturze popowstaniowej, gdy nieobecność poległych w 1863 i 1864 roku bądź zesłanych na Sybir mężów, ojców czy braci zmieniała relacje w polskich domach. Taki

\footnotetext{
${ }^{24}$ Tamże, s. 96.

${ }^{25}$ Ciekawe w tym kontekście są losy chado, które mniej więcej do epoki Meiji (okres panowania cesarza Mutsuhito, 1868-1912) było domeną mężczyzn (zob. przypis 16). Z trzydziestu sześciu wywiadów przeprowadzonych w 2011 roku przez antropolożkę Kaeko Chibę (trzydzieści trzy z kobietami, trzy z mężczyznami) wynika, że część jej rozmówców sądzi, że ceremonia parzenia herbaty jest niedostępna dla mężczyzn („He confessed that he believed that men were not allowed to practise tea ceremony!”), $\mathrm{K}$. Chiba, Japanese women, class and the tea ceremony. The voices of tea practitioners in northern Japan, 2011, s. 17, 101.
}

${ }^{26}$ Początek procesu wielkich zmian w rodzinie upatruje się w rewolucji francuskiej 1789 roku.

${ }^{27}$ Nasilony proces migracji ze wsi do miast, powszechna urbanizacja i industrializacja, eksplozja demograficzna spowodowały zmiany w strukturze ilościowej najmniejszej komórki społecznej. Rodziny wielopokoleniowe ustępowały miejsca trzypokoleniowym, a nawet dwupokoleniowym. Takim przeobrażeniom ilościowym towarzyszyły zmiany jakościowe różnego typu, począwszy od wzrostu liczby dzieci nieślubnych w dużych ośrodkach przemysłowych (zob. I. Ihnatowicz i inni, Społeczeństwo polskie od X do XX wieku, wyd. 3, Warszawa 1996, s. 452-453) po odmienny styl prowadzenia kuchni wielopokoleniowych. Należy podkreślić, że zmiany miały różny charakter i występowały z zmieniającym się nasileniem w zależności od typu rodziny (zob. przyp. 9).

${ }^{28}$ Opisywane przeobrażenia dotyczą przede wszystkim wyższych warstw społecznych, rodzin arystokratycznych, ziemiańskich czy bogatych familii mieszczańskich. To one najszybciej reagowały na analogiczne zmiany w krajach Europy Zachodniej. O historii rodzin w interesującym okresie zob. m.in. Rodzina — prywatność - intymność. Dzieje rodziny polskiej w kontekście europejskim, red. D. Kałwa, A. Walaszek, A. Żarnowska, Warszawa 2005. 
stan rzeczy dawał się we znaki i córkom, zmuszonym do pomocy matce i matkom, które zwyczajowo kilkuletnią edukację córek w zakresie prowadzenia domu musiały znacznie przyspieszyć. Szczególnie młode panie domu nie były przygotowane do zarządzania gospodarstwem samodzielnie, bez wsparcia mężczyzny. Musiały przejąć obowiązki męża i sprawnie kierować domem, ograniczając się nie tylko do organizacji samych posiłków, ale do zdobywania surowców, co częściej należało do obowiązków męża ${ }^{29}$.

Pod nieobecność mężczyzny nastąpiły także zmiany w zakresie ścisłej kultury stołu —reorganizacji ulegała m.in. hierarchia zajmowania miejsc przy posiłkach ${ }^{30}$. Głową rodziny był zazwyczaj najstarszy przedstawiciel rodu, jednak w sytuacjach nietypowych (np. konflikty zbrojne, przedłużająca się nieobecność pana domu) to kobieta zajmowała główne miejsce przy stole. Nierzadko była to młoda żona, która dbała, by rodzina zasiadała do posiłków wspólnie. W tych niespokojnych okolicznościach, naznaczonych stratami bliskich, częstymi przenosinami ${ }^{31}$ czy kolejnymi represjami, także podtrzymywanie domowego miru i wspólne picie herbaty ${ }^{32}$ stawały się ważnymi czynnościami, których organizacja w pełni spoczywała na barkach pań domu, zarówno młodych mężatek, jak i córek. Pod wpływem okoliczności zewnętrznych musiały one dorosnąć szybciej niż to miało miejsce w czasach względnego choćby pokoju.

Wiedziała o tym młoda bohaterka Rodziny Brochwiczów - powieści Elizy Orzeszkowej, opisującej ciężkie losy polskiego ziemiaństwa po powstaniu styczniowym. Anna Siecińska w stu procentach wypełniała obowiązki młodej gospodyni, pamiętając, że — bez względu na najgorsze wydarzenia - w kuchni powinien szumieć „gotujący się samowar" ${ }^{33}$. Gdy „wiejska służąca, w grubym fartuchu i chustce na głowie wniosła samowar” ${ }^{34}$, Anna obiecywała zrozpaczonemu rodzeństwu: „zaraz urządzę dla was wszystkich herbatę" 35 . To nikt inny, jak tylko ta młoda kobieta, spowodował, że przykry czas przenosin stał się dla rodzeństwa dniem może nawet więcej jak znośnym:

\footnotetext{
${ }^{29}$ Należy podkreślić, że to naturalne osłabienie patriarchatu wywołane nieobecnością mężczyzny w domu miało charakter chwilowy. Pierwotne relacje wracały do łask po powrocie mężów, ojców i braci. Jednak korelacja między emancypacją kobiet a wszelkiego rodzaju działaniami wojennymi była często podnoszona w literaturze przedmiotu. Nierzadko najbardziej podatne na osłabienie patriarchatu w relacjach domowych były młode panie domu czy niezamężne córki, którym trudno było wrócić do stanu sprzed, choćby krótkich okresów emancypacyjnych.

${ }^{30}$ Od zawsze czynnikami najważniejszymi przy zajmowaniu miejsc przy stole były przede wszystkim płeć i wiek. Ten układ był wariabilny i podlegał wahaniom pod wpływem okoliczności dodatkowych, np. gość zajmował niekiedy miejsce gospodarza, jubilat miał prawo wyboru miejsca i inne.

${ }^{31}$ Nierzadko łączącymi się z degradacją majątkową czy społeczną rodziny.

${ }^{32} \mathrm{O}$ tym, że picie herbaty było zwyczajem bardzo ważnym w drugiej połowie XIX wieku, a jego brak był zauważalny przez rodzinę, świadczy fragment: „Stół przed kanapą nakryty był białym obrusem i zastawiony talerzami z prostego fajansu; były to przygotowania do wieczerzy, zastępującej dla mieszkańców dworku herbatę, niepijaną od wielu już tygodni, to jest od czasu, gdy druga rata nadzwyczajnych podatków opłaconą przez Józefa została, a w domu nie było pieniędzy na opłacenie towarów, branych dotąd w korzennym sklepie sąsiedniego miasteczka" (E. Orzeszkowa, Rodzina Brochwiczów, Warszawa 1885, s. 98).

${ }^{33}$ E. Orzeszkowa, Rodzina Brochowiczów, t. 2, Warszawa 1885, s. 77.

${ }^{34}$ Tamże, t. 1, s. 78.

${ }^{35}$ Tamże.
} 
Było to w tym smutnym, rodzinnym zebraniu pierwsze słowo, swobodniejszym nieco tonem wymówione. Na bladych ustach młodej dziewczyny, która je wymawiała, zarysował się uśmiech, zarazem wzięła ona w objęcia młodsze dziecię i posadziła ja na kanapie; starszych chłopców przyprowadziła do stołu, po czym przysunąwszy dla siostry jedyne poręczowe krzesło, jakie znajdowało się w izbie, i otuliwszy ją ciepłym szalem, zajęła się przyrządzaniem gorącego napoju. [...]

Anna spełniała gospodarskie swe zajęcia cicho i zręcznie; przed każdą z osób siedzących przy stole stawiała szklankę z gorącym napojem, krajała chleb świeży, lecz czarny, i rozdawała go dzieciom ${ }^{36}$.

\title{
SMAKI STAROŚCI I MłODOŚCI W POWIEŚCI POSZCZECIŃSKIEJ ${ }^{37}$
}

„Sytuacje związane z jedzeniem i pokarmami mają w literaturze przełomu lat 40. i 50. charakter epizodyczny" ${ }^{38}$, w analizowanych utworach dominowały kulinaria akcydenso$w^{39}$. Mimo tego widocznego zaniedbania kultury stołu, szczegółowa analiza powieści tendencyjnej 1949-1955 pozwala wskazać stałe elementy w budowaniu scen związanych z jedzeniem i ustalić, w jaki sposób wiek wpływa na wybory żywieniowe postaci.

\section{Wisława Szymborska przypominała, że}

\author{
W planie \\ w planie \\ w Sześcioletnim Planie \\ trzeba \\ trzeba \\ szczęśliwych rodzin ${ }^{40}$,
}

\footnotetext{
${ }^{36}$ Tamże, s. 78 i 80.

${ }^{37} \mathrm{~W}$ artykule używa się synonimicznych określeń: powieść doby realizmu socjalistycznego, powieść poszczecińska, powieść produkcyjna, powieść socrealistyczna, powieść tendencyjna 1949-1955, proza narracyjna.

Proza realizmu socjalistycznego ma bogatą bibliografię, oto publikacje najbardziej interesujące w kontekście obecnych rozważań: M. Brzóstowicz, „W sześcioletnim planie trzeba szczęśliwych rodzin”. O wizerunku rodziny w prozie realizmu socjalistycznego, „Pamiętnik Literacki” 1995, z. 3, s. 45-68; M. Kierczyńska, Spór o realizm. Szkice krytyczne, Warszawa 1951; J. Pyszny, Co jada bohater? Kod kulinarny literatury socrealistycznej, czyli dieta a światopoglad, [w:] Pokarmy i jedzenie w kulturze..., s. 215-245; K. Sałdecka, „Żjemy wciąż jeszcze na rusztowaniach...” Wizerunek kobiety w polskich powieściach doby realizmu socjalistycznego, Toruń 2013; J. Smulski, Od Szczecina do... Października. Studia o literaturze polskiej lat pię́́dziesiątych, Torun 2002; W. Tomasik, Polska powieść tendencyjna 1949-1955. Problemy perswazji literackiej, Warszawa 1988; W. Tomasik, Proza narracyjna, [w:] Stownik realizmu socjalistycznego, red. Z. Łapiński, W. Tomasik, Kraków 2004, s. 216-224; W. Tomasik, Stowo o socrealizmie. Szkice, Bydgoszcz 1991.

${ }^{38}$ J. Pyszny, dz. cyt., s. 216.

${ }^{39}$ Bohaterowie powieści produkcyjnej bardzo często posilali się „w biegu”, np. w czasie przerw w pracy przegryzali kanapki i pili sporą ilość kawy. Także pozostałe zachowania kulinarne (spożywanie rodzinnych obiadów, wizyty w restauracjach) były relacjonowane w utworach bardzo oszczędnie — proza narracyjna „nie rozpieszcza” czytelnika zmysłowymi opisami potraw czy okolicznościami spożywania posiłków.

${ }^{40}$ W. Szymborska, Dlatego żyjemy, Warszawa 1952; M. Głowiński, Rytuat i demagogia. Trzynaście szkiców o sztuce zdegradowanej, Warszawa 1992; T. Wilkoń, Polska poezja socrealistyczna w latach 1949-1955, Gliwice 1992.
} 
wskazując na dwa z podstawowych tematów podejmowanych przez prozę produkcyjną: plan gospodarczy $1950-1955^{41}$ i socjalistyczną rodzinę $e^{42}$.

$\mathrm{Na}$ gęsto po Polsce rozsianych budowach pracowali młodzi inżynierowie, majstrowie oraz szeregowi robotnicy. Zdarzało się, że zatrudnienie znajdowali w pobliżu swoich stałych miejsc zamieszkania, nierzadko jednak byli zmuszeni udać się na drugi koniec Polski. Niezależnie od tego, czy — w pogoni za chlebem — przenosił się tylko młody ojciec rodziny, czy też migracje dotykały całej najmniejszej komórki społecznej, organizacji w nowej rzeczywistości ${ }^{43}$ wymagała też sfera dotycząca jedzenia. Tym, co odpowiadało na potrzeby nowo przybyłych, były placówki zbiorowego żywienia. W powieściach narracyjnych młodzi budowniczowie Polski Ludowej, podnoszący swoje kwalifikacje zawodowe na kursach doszkalających czy na studiach, nierzadko „spotykali się w akademickiej stołówce” ${ }^{44}$. Także robotnicy niewykorzystujący szans, jakie dawała akcja wychowawczo-edukacyjna, korzystali z obecnej na miejscu infrastruktury gastronomicznej, a w wypadku braku tejże jadali w organizowanych naprędce prowizorycznych lokalach, jak to miało miejsce w powieści Przy budowie, w której w jednym z baraków mieściła się ,świetlica i stołówka” ${ }^{45}$.

Postacie literackie chętnie korzystały z wszechobecnych jadłodajni nie tylko poza miejscem zamieszkania. Takie rozwiązanie nie powinno dziwić nawet w wypadku młodych małżeństw, gdyż w dobie aktywizacji zawodowej kobiet zbiorowe żywienie było forsowane przez gremia państwowe, zwalniając kobietę z obowiązku przygotowania domowych posiłków. Z taką sytuacją mamy do czynienia we wspomnianej powieści Przy budowie, której bohaterowie — młode, z niespełna dwuletnim stażem, małżeństwo Janki i Pawła - korzystało z dobrodziejstw zbiorowego żywienia. Mąż, dowiedziawszy się o rychłym oddelegowaniu na plac budowy, „zjadł jeszcze obiad w stołówce i wyszedł na miasto"46 , by odebrać Jankę, która właśnie kończyła pracę.

Przedstawiona w powieści Tadeusza Konwickiego scena należy do kategorii kulinariów akcydensowych — autor nie skupiał się na drobiazgowym opisie tego, co jadali małżonkowie, nie informował czytelnika o wyglądzie stołówki. Jednak dla historyka żywienia, znającego kod kulinarny socrealizmu ${ }^{47}$, scena ta jest dość oczywistym

${ }^{41}$ M. Brzóstowicz-Klajn, W. Tomasik, Planu sześcioletniego temat, [w:] Stownik realizmu socjalistycznego..., s. $195-200$.

${ }^{42}$ M. Brzóstowicz-Klajn, Rodziny i domu obraz, [w:] tamże, s. 297-302.

${ }^{43}$ Szczególnie dla młodych matek dotkliwy był brak żłobków, przedszkoli i całej infrastruktury ułatwiającej życie rodzinom. Swoje niezadowolenie wyrażały bohaterki Dziewczyny: „[...] głupiego żłobka nie można postawić, a co dopiero świetlicę" (J. Pierzchała, Dziewczyna, Warszawa 1952, s. 16).

${ }^{44}$ Andrzej i Stefan „spotykali się w akademickiej stołówce przy kasie, by odebrać stypendium, żyli tym samym powietrzem, tymi samymi sprawami" (J. Pierzchała, $d z$. cyt., s. 165).

${ }^{45}$ T. Konwicki, Przy budowie, Warszawa 1950, s. 10. Powieść ciekawa choćby z tego względu, że wyszła jako pierwszy i zarazem ostatni tom serii „W kuźni planu sześcioletniego”.

${ }^{46}$ Tamże, s. 7.

${ }^{47}$ Zob. m.in. S. Bednarek, W socjalistycznej kuchni, [w:] Nim będzie zapomniana. Szkice o kulturze PRL-u, red. S. Bednarek, Wrocław 1997, s. 236-243; J. Pyszny, dz. cyt. 
sygnałem tego, że życie młodych zorganizowane jest zgodnie z propagowaną przez władze polityką rodzinną, której zasadniczym (choć ukrywanym przed opinią publiczna) punktem była dekonstrukcja więzi scalających „podstawową komórkę społeczną”. Zabiegi perswazyjne, mające na celu, jeśli nie wywyższyć, to przynajmniej zrównać rangę obiadów stołówkowych z domowymi, były kierowane przede wszystkim do dwudziesto- i trzydziestolatków, którzy tworzyli zręby nowej Polski. Zbiorowe żywienie było jednym z podstawowych elementów kultury kulinarnej PRL-u. W przestrzeni miejskiej dominowały stołówki i bary mleczne, które dla młodych, zarówno kobiet i mężczyzn, były ułatwieniem w godzeniu obowiązków domowych z zawodowymi, dla starszych - stanowiły dostępną finansowo alternatywę wobec obiadów rodzinnych. Młoda Polka mogła, realizując postulat „nowego człowieka”, oddać się pracy zawodowej. Cedowała obowiązek karmienia domowników na państwowe placówki żywieniowe. Dlatego wszyscy członkowie zdekonstruowanej socjalistycznej rodziny korzystali z dobrodziejstw barów mlecznych i stołówek, nie wyłączając dzieci, o czym mowa w powieści Wegiel, której młodziutki bohater, Piotruś,

Dzielił się swoim, rzadko zresztą przynoszonym, śniadaniem z Brygidą Pielkówną, która z domu nigdy nie dostawała nic do jedzenia. Potem, gdy w szkole staraniem jakiejś nie znanej Piotrusiowi pani Urszuli zaczęto wydawać darmowe śniadania, dbał o to, żeby swej chorowitej przyjaciółce wybierać kakao bez kożucha i kawałki chleba lepiej posmarowane smalcem ${ }^{48}$.

Powieść produkcyjna oceniała dodatnio placówki zbiorowego żywienia, nie zapominając o bardziej ekskluzywnych miejscach spotkań przy kawie czy wykwintnym daniu — tych scen jest jednak zdecydowanie mniej. Młodziutką Agnieszkę Nieborzankę spotykamy na kawie z Jerzym Morawieckim, co ciekawe w tej samej cukierni, w której profesor spotykał się przed ślubem ze swoją żoną. Różnica wieku dzieląca ich obydwoje nie umknęła profesorowi, gdyż

[...] przyszło mu na myśl, że w oczach ludzi siedzących przy sąsiednich stolikach — ich spotkanie musiało wyglądać na schadzkę. Agnieszka była przecież ładna. Żonaty mężczyzna z obrączką na palcu i młoda dziewczyna o czystych, spokojnych ustach ${ }^{49}$.

Jednak nawet jeśli inżynierów, nauczycieli i oddanych pracy propagandowej młodych robotników spotykamy w restauracjach, to i tak jedzą oni mało wyszukane potrawy, jak w przypadku agitującego za Kongresem Zjednoczenia Partii Robotniczych Andrzeja, który

[...] z innymi towarzyszami z dzielnicy wyjeżdżał w teren. Pracowali z ochotą, wyjeżdżali odkrytą ciężarówką na wiatr, na deszcz. Ręce sztywniały z zimna, ciało przejmował chłód. W napotkanych restauracjach jedli szybko kiełbasę z chlebem, zapijali ciepłym piwem, kieliszkiem wódki ${ }^{50}$.

\footnotetext{
${ }^{48}$ A. Ścibor-Rylski, Wegiel, Warszawa 1950, s. 165.

${ }^{49}$ K. Brandys, Obywatele, Warszawa 1955, s. 70.

${ }^{50}$ J. Pierzchała, dz. cyt., s. 170.
} 
Nie zawsze bohaterowie powieści socrealistycznej jadali tylko poza domem. Niezależnie od tego, czy kobieta była aktywna zawodowo, czy poświęcała się prowadzeniu domu, obowiązek przyrządzania posiłków spoczywał na niej. Forsowany w przestrzeni publicznej obraz „nowej rodziny” nie zakłócał „kuchennego matriarchatu”, bowiem proza poszczecińska stawiała wysokie wymagania ${ }^{51}$ zarówno młodym, jak też dojrzałym kobietom, które w „nowej rzeczywistości” powinny bezkolizyjnie godzić rolę pani domu z aktywnością zawodową. Taka sytuacja miała miejsce w domu państwa Morawieckich, którzy do obowiązków dojrzałej gospodyni zaliczali właściwe przyjęcie męża po pracy — fakt, że Krystyna pracowała zawodowo ${ }^{52}$ nie zwalniał jej z przywileju (obowiązku?) podania herbaty, a następnie uprzątnięcia wszystkiego ze stołu i umycia naczyń ${ }^{53}$.

Nie wszystkie bohaterki powieści tendencyjnej 1949-1955 były aktywne zawodowo. Zarówno młode, jak też dojrzałe związki, równie chętnie decydowały się na tradycyjny model, w którym „[...] małżeństwo przedstawia się jako zwyczajną umowę, zgodnie z którą mężczyzna zarabia na utrzymanie małżonki i potomstwa, natomiast kobieta oddaje w zamian większą część swoich sił, dbając o kuchnię, ogród, robiąc zakupy" ${ }^{4}$. Jednak w powieści doby realizmu socjalistycznego kobieta była zmuszona oddawać także część swoich sił intelektualnych. Młody mąż, dojrzewający do właściwej postawy obywatelskiej, jak też dojrzały małżonek, w pełni rozumiejący tajniki filozofii marksistowskiej, czuli potrzebę, by doszkalać i politycznie uświadamiać swoje partnerki. One, przyjmując rolę wychowanek męża, uczestniczyły w dwuosobowych, domowych wykładach na temat zagadnień leninizmu i marksizmu — milcząco wspierały małżonków w kwestiach zawodowych ${ }^{55}$. Warto odnotować, że nawet kobiety pracujące podlegały tej swoistej edukacji, a posiłki spożywane w domu stały się okazją do tego, by uwypuklić role, jakie pełnili małżonkowie. Czasem spożywali obiad czy kolację wspólnie, jednak nierzadko żona jedynie podawała posiłek, sama do niego nie zasiadając. Taki modus operandi nie był obcy małżeństwu Morawieckich, gdyż pytanie profesora "- Co porabiałaś?” ${ }^{56}$ pozostało bez odpowiedzi, bo pytający sam zaczął opowiadać o swoim dniu.

W okresie realizacji planu sześcioletniego niebagatelne znaczenie miała mobilność młodych mężczyzn, szczególnie tych niezwiązanych jeszcze więzami małżeńskimi. Większość robotników pochodziła z biednych rodzin, a tym, co z sobą najczęściej zabierali na drogę i pierwsze dni w nowym miejscu, było przygotowane z miłością

\footnotetext{
${ }^{51}$ Nierzadko niemożliwe do spełnienia.

${ }^{52} \mathrm{~W}$ większości powieści socrealistycznych nie znajdziemy szczegółowych informacji na temat zawodów, jakie wykonują kobiety. Czytelnik musi się zaspokoić zdawkowymi informacjami.

${ }^{53}$ K. Brandys, dz. cyt., s. 15-17.

${ }^{54}$ K. Sałdecka, dz. cyt., s. 35.

${ }^{55}$ Łączenie życia zawodowego z prywatnym to jeden z podstawowych warunków wzorcowego małżeństwa socjalistycznego. ,[...] szczęście w małżeństwie może zaistnieć dopiero wtedy, gdy partnerzy potrafią połączyć sprawy osobiste i sprawy partii oraz żyć „kolektywnie” (K. Sałdecka, dz. cyt., s. 35).

${ }^{56} \mathrm{~K}$. Brandys, $d z$. cyt., s. 15.
} 
jedzenie. Nie inaczej było w wypadku młodziutkiego Leona Zawiły, któremu ciotka spakowała „do worka pół bochenka chleba i osełkę starego masła" ${ }^{7}$. Młodzieniec wyjeżdżał do pracy przy umiarkowanej aprobacie krewnej, która, lękając się o możliwe niedogodności, zapewniała, że chłopak może wrócić w każdej chwili — nawet bez pieniędzy. Jednak, kiedy po jakimś czasie Leon wybrał dalszą pracę przy torach i nie podjął żadnych starań o rękę bogatej Ziemkówny, dostał jasny sygnał dezaprobaty, gdyż

[...] kiedy wyjeżdżał z powrotem do roboty, ciotka, nie odezwawszy się ani słowem, ostentacyjnie przygotowała bochen chleba i osełkę masła zawiniętą w zwykły pakowy papier (zawsze zawijała w bielutką merlę) $)^{58}$.

W literaturze doby realizmu socjalistycznego podstawową funkcją jedzenia było podtrzymywanie procesów życiowych, dlatego „połączenie sfery konsumpcji i erotyzmu: poetyckie przedstawienie biologicznych popędów, fizjologii płci i związanych z nią procesów" ${ }^{99}$ było rzadkością. W prozie narracyjnej doszło do kastracji erotyzmu i seksualności ${ }^{60}$, co w konsekwencji skutkowało pozbawieniem bohaterów zmysłowej przyjemności ze spożywania pokarmów. Mimo tego, że „erotyzm jedzenia” nie przystał powieści tendencyjnej, znajdziemy kilka miejsc, które na swój specyficzny sposób „mocowały się" z tym zagadnieniem. Sensualnymi scenami są te, w których dojrzali bohaterowie obserwowali swoje żony w przestrzeni mieszkania:

Śledził jej ruchy, gdy zbierała ze stołu naczynia; zawsze podziwiał urok tych gestów: były oszczędne, celowe, prawie niedostrzegalne. Widział jej plecy, czarny sweter, ładną pochyłość ramion, włosy związane z tyłu. Trzymała się zadziwiająco prosto, nigdy nie widział jej zgarbionej. Gdy tak stała przy kuchni, odwrócona do niego tyłem, można ją było wziąć za młodą dziewczynę ${ }^{61}$.

\section{Ciekawą na tle aseksualnej prozy poszczecińskiej jest scena z Dziewczyny:}

Opodal Andrzej pił wodę. Młodziutka dziewczyna przytrzymywała delikatnie wiadro, które on chciwie objął rękami.

— Obiadu dziś nie jadłem — powiedział...

— O ty biedaku — rozczuliła się dziewczyna przy studni — umrzesz od roboty. Trzeba jeść. Nie ma kto o ciebie zadbać. U matki już ci pewnie nie smakuje?

Genowefa szorstko otarła się o rozgadaną dziewczynę. Pociągnęła Andrzeja za sobą. Rozdrażniła ją ta rozmowa. Odezwało się w niej nagle uczucie do Andrzeja, w sercu wezbrała siła, nieustępliwość.

— Co się łasisz? - powiedziała.

Zaprzeczył ${ }^{62}$.

\footnotetext{
${ }^{57}$ T. Konwicki, $d z$. cyt., s. 9.

${ }^{58}$ Tamże, s. 55.

${ }^{59}$ J. Grądziel-Wójcik, Erotyzm jedzenia [online], dostęp 2 sierpnia 2015, dostępny: $<$ http://www.sensualnosc.ibl.waw.pl/pl/articles/erotyzm-jedzenia-583/>.

${ }^{60}$ K. Sałdecka, dz. cyt., s. 17-30.

${ }^{61}$ K. Brandys, $d z$. cyt., s. 16.

${ }^{62}$ J. Pierzchała, dz. cyt., s. 53-54.
} 
Należy zgodzić się ze Stefanem Bednarkiem, że „dominacja ideologii w PRL-u nie mogła się nie ujawniać także w dziedzinie jedzenia" ${ }^{63}$, choć nie wszystkie kulinaria akcydensowe czy bloki kulinarne trzeba interpretować jako element frontu ideologicznego w kuchni ${ }^{64}$. Tym, co nie powinno podlegać działaniom propagandowym, jest „pamięć smaku” - ta specyficzna właściwość ludzkiego umysłu, która pozwala wracać do kulinarnych krain dzieciństwa i najbardziej istotnych momentów życia. Z takim obrazowaniem mamy do czynienia w powieści Obywatele, gdy profesor przypomniał sobie kawę pitą w „cukierni Galińskiego” ${ }^{65}$, na pierwszym spotkaniu z Krystyną:

Morawiecki przypomniał sobie, że tutaj spotykali się z Krystyną, jeszcze przed ślubem, w pierwszych miesiącach znajomości. Pochylił się nad stolikiem, usiłując odpędzić tę myśl. Wybierali zwykle miejsce w głębi, koło okna. Wisiał tam jakiś obraz, czy nie reprodukcja „Grunwaldu”?66

Wspomnienia Morawieckiego należały do, nielicznie w prozie doby realizmu socjalistycznego reprezentowanej, grupy bloków kulinarnych, dlatego wypada zacytować je w całości:

Kiedyś spóźniła się o pół godziny. Czekając kreślił na marmurowym blacie jej imię palcem umaczanym w rozlanej kawie. Zastała go wpatrzonego w powalany stolik, nie zdążył zamazać imienia, gdy nadeszła, i przy powitaniu poplamił jej nową rękawiczkę. Tak wyglądały jego oświadczyny. Czy to była jesień? Nie, wiosna, wczesna wiosna. Spóźniła się wskutek burzy; po wiosennej burzy poprosił ją o rękę. A zachorowała jesienią. Dwie pory odległych od siebie lat. Czas, dzielący wiosnę od jesieni, nie zawsze bywa czasem urodzaju ${ }^{67}$.

Jerzy wiedział już o chorobie żony — być może nadzieja, jaką miał na jej wyzdrowienie, kazała mu wracać do ich pierwszych spotkań. Jednak po śmierci ukochanej rana była zbyt świeża i mężczyzna wspominał smaki dzieciństwa, które były ucieczką przed samotnością i pustką, jaka mu została:

Morawiecki przymknął oczy usiłując sobie odtworzyć jakiś dawny dzień z dziecinnych lat, kiedy budziły go podobne odgłosy. Usłyszał dreptanie drobnych kroczków w kuchni: ktoś się tam krzątał i nucił. Nie chciało mu się odemknąć oczu: wyobraził sobie przez chwilę, że obok, w kuchni, matka szykuje dymiącą, zbożową kawę, można więc jeszcze przyłożyć głowę do poduszki ${ }^{68}$.

Dominujące w literaturze przedmiotu przekonanie, że proza poszczecińska oszczędnie przedstawiała sferę kulinarną jest słuszne, jednak brak tej tematyki oceniany bywa ambiwalentnie. Nieobecność problematyki związanej z jedzeniem w powieściach, w których nierzadko obrazy funkcjonowania domu i rodziny były podstawowymi

\footnotetext{
${ }^{63}$ S. Bednarek, W socjalistycznej kuchni, [w:] Nim będzie zapomniana..., s. 239.

${ }^{64}$ Tamże.

${ }^{65}$ K. Brandys, dz. cyt., s. 69.

${ }^{66}$ Tamże, s. 69-70.

${ }^{67}$ Tamże, s. 70.

${ }^{68}$ Tamże, s. 572.
} 
budulcami fabuły, wydaje się być znaczącym niedociągnięciem. Zarazem omówione sceny kulinarne dowodzą konieczności dalszych badań nad tym zagadnieniem.

W artykule została omówiona korelacja między wiekiem bohaterów literackich a sposobem prezentowania tematyki związanej z jedzeniem. Na podstawie analizy kulinariów akcydensowych podkreślono wagę nawet najskromniejszych przejawów kultury stołu w odtwarzaniu „smaku” (nie tylko) prozy tendencyjnej XIX wieku i powieści socrealistycznej. Zwrócono uwagę, iż wykonywanie pewnych obowiązków domowych, np. parzenie i podanie herbaty, spełniało różną funkcję w zależności od wieku osoby przygotowującej napar.

Analiza wybranych utworów prozy poszczecińskiej przekonuje, iż proklamowane w dobie realizmu socjalistycznego równouprawnienie było jedynie niespełnialnym postulatem. W bezkolizyjnym godzeniu pracy zawodowej z życiem rodzinnym pomagały młodym małżeństwom placówki zbiorowego żywienia. Jednak w powieściach dominował nadal „kuchenny matriarchat”, obecny zarówno w domach młodych mężatek, jak i dojrzałych gospodyń.

Anna Ż.M. Wiśniewska-Grabarczyk

Can Literature „SPEaK culinary”? On Example of Categories of Elderly and Youth

Summary

In this paper I examine how culinary scenes correspond with categories of elderly and youth. Texts I analyse differ in terms and the amount of culinary aspects - from simple enumeration of side and main dishes to more detailed culinary scenes which are often remembered by the readers. The author of this paper is going to examine the ritual of tea brewing as performed by nubiles which is characteristic for the $19^{\text {th }}$ century literature. The most important is to reveral causes and consequences of this ritual. In the second part of the paper there will be analysed socialist-realist novel, which depicts old and young people engaged in the act of eating. I debate whether the elderly and the youth are depicted similarly in the culinary context. Additionally, I devote some attention to gender differences.

Słowa kluczowe: kulinaria w literaturze, motyw jedzenia, kultura stołu, literatura tendencyjna, literatura socrealistyczna

Keywords: cuisine in literature, eating motives, food culture, tendency literature, socialist realism in literature 